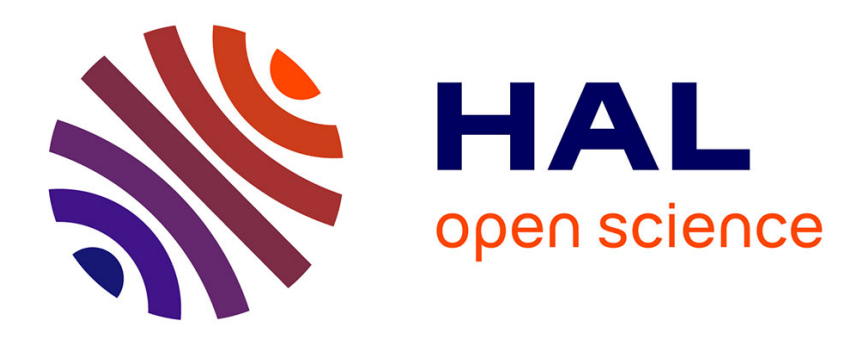

\title{
Foraging patterns of soil springtails are impacted by food resources
}

Matthieu Chauvat, Gabriel Perez, Jean-François Ponge

\section{To cite this version:}

Matthieu Chauvat, Gabriel Perez, Jean-François Ponge. Foraging patterns of soil springtails are impacted by food resources. Applied Soil Ecology, 2014, 82, pp.72-77. 10.1016/j.apsoil.2014.05.012 . hal-01009691

\section{HAL Id: hal-01009691 https://hal.science/hal-01009691}

Submitted on 18 Jun 2014

HAL is a multi-disciplinary open access archive for the deposit and dissemination of scientific research documents, whether they are published or not. The documents may come from teaching and research institutions in France or abroad, or from public or private research centers.
L'archive ouverte pluridisciplinaire HAL, est destinée au dépôt et à la diffusion de documents scientifiques de niveau recherche, publiés ou non, émanant des établissements d'enseignement et de recherche français ou étrangers, des laboratoires publics ou privés. 


\section{Foraging patterns of soil springtails are impacted by food resources}

2

3

4 Matthieu CHAUVAT ${ }^{1 *}$, Gabriel PEREZ ${ }^{1}$, Jean-François PONGE ${ }^{2}$

$5{ }^{1}$ Normandie Univ, EA 1293 ECODIV-Rouen, SFR SCALE, UFR Sciences et Techniques, 76821

6 Mont Saint Aignan Cedex, France

$7{ }^{2}$ Muséum National d'Histoire Naturelle, CNRS UMR 7179, 4 avenue du Petit-Château, 91800

8 Brunoy, France

9

10

$11{ }^{*}$ Corresponding author at Normandie Univ, EA 1293 ECODIV-Rouen, SFR SCALE, UFR

12 Sciences et Techniques, 76821 Mont Saint Aignan Cedex, France Phone: +33 232769441 ;

13 Email: matthieu.chauvat@univ-rouen.fr

14

15

16

17

18 


\section{ABSTRACT}

Movement of soil microarthropods associated to searching or foraging behaviour has received scanty attention and remained largely unexplored. However, rare studies on soil Collembola suggested that their exploratory behaviour is an important feature of population dynamics. In the current study based on a microcosm experiment we tested the influence of food sources tied to a distant patch on the foraging behaviour of springtails. The microcosms consisted of five separate $5 \mathrm{~cm}$ sections bound together. Only the last part of the microcosms (section 5) differentiated the 3 treatments with no food (C), microflora (M) or microflora + plant $(\mathrm{M}+\mathrm{P})$. Collembola were introduced into the first section. The mean covered distance of total collembolan differed between all the treatments. It continuously increased from $0.9( \pm 0.3) \mathrm{cm}$ in C through $4.7( \pm 1.0) \mathrm{cm}$ in $M$ to $7.4( \pm 1.2) \mathrm{cm}$ within $M+P$. Concomitantly, the mean covered distance was also influenced by the factor "life-form" with on average $7.3 \mathrm{~cm}$ covered by the epedaphic species which was $73.8 \%$ more than hemiedaphic and $82.5 \%$ more than euedaphic. Even if differences between life-forms were detected, our results also revealed differences of exploratory pattern between species belonging to the same life-form. Our study clearly shows that springtails are reactive to the quality of their environment, in particular food sources. 


\section{INTRODUCTION}

Studying the movement sensu lato of organisms is a key topic in ecology (Dieckmann et al., 1999; Levin et al., 2003). Processes like migration, dispersal or foraging influence the dynamics of populations, the distribution and abundance of species and therefore the community structure. Migration is furthermore known to be involved in speciation processes and in the evolution of life-history traits (Winker, 2000). Consequently movements of organisms affect ecosystem functioning by modifying living assemblages and the nature and strength of biotic relationships. One main reason that forces organisms to move, explore or disperse is foraging. For example, animals can be attracted by the odour of their food (Auclerc et al., 2010; Salmon and Ponge, 2001). They may also be forced to move owing to overcrowding or antagonism from competing species (Ronce, 2007).

Many data and models of foraging, dispersal or migration are now available for many organisms (Nathan, 2001). However, with the exception of a few groups like ants (Lenoir, 2003) or soil living-herbivores (Schallhart et al., 2011), movement associated to searching or foraging behaviour within the soil has received scanty attention and remained largely unexplored (Hassall et al., 2006; Mathieu et al., 2010). However, rare studies on soil animals suggested that their searching and foraging behaviour is an important feature of population dynamics (Bengtsson et al., 1994a; Bengtsson et al., 2002b; MacMillan et al., 2009).

Collembola constitute a dominant, well investigated and diverse soil microarthropod group. Many studies have proven the direct or indirect contribution of Collembola to belowground functioning such as $\mathrm{N}$ mineralisation, soil respiration or leaching of dissolved organic carbon (Filser, 2002). Many indirect effects of Collembola on soil processes operate through interactions with the microflora. Several studies higlighted that Collembola critically depend on food sources provided by the soil microflora (Hopkin, 1997). 
Gisin (1943) described three typical soil collembolan life-forms based on morphology and

64 habitat. Briefly, epedaphic species are usually large bodied species, have a high metabolic 65 activity, consume a food substrate of a high quality and are surface-dwellers. Conversely, euedaphic species are deep-living species that consume low-quality food and have a low

67 metabolic activity. Euedaphic species are small-sized, colorless with reduced appendices (e.g. furca, antennae, leg). Finally, the hemiedaphic group includes species sharing

69 intermediate attributes (Petersen, 2002; Rusek, 1989). Collembolan assemblages are thus well-structured on a vertical spatial scale matching the resources dispatched by plants either 71 above- (litterfall) or belowground (roots and root exudates).

72 While several studies focused on the dispersal of springtails (Auclerc et al., 2009; 73 Bengtsson et al., 2002a; Ojala and Huhta, 2001), few focused on foraging (Bengtsson and 74 Rundgren, 1988; Bengtsson et al., 1994b; Hagvar, 2000). According to the fact that dispersal 75 capacity relates beside other factors to locomotor activity, comparatively large epedaphic 76 springtails with good jumping skills and well-developed legs should be more efficient 77 foragers than euedaphic species. However, species with directional sense perception may 78 also have a high probability to forage successfully (Mitchell, 1970).

79 In the current study based on a microcosm experiment we thus wanted to test the 80 influence of two food sources tied to a distant patch on the foraging behaviour of springtails. 


\subsection{Microcosm setup}

\subsubsection{Substrate}

The substrate used was sourced from a deciduous forest (Fagus sylvatica) located within the Campus of the University of Rouen. The soil was an endogleyic dystric Luvisol (FAO) developed on more than $80 \mathrm{~cm}$ of loess (lamellated siltloam) lying on clay with flints. The humus form is a dysmoder. The C: $\mathrm{N}$ ratio of the A horizon was of about 15.3 and the $\mathrm{pH} \mathrm{H}_{2} \mathrm{O}$ 3.9. We collected on a square meter the $\mathrm{F}$ and $\mathrm{H}$ organic horizons of the topsoil. Once in the laboratory, one part of the organic substrate collected was used in the microcosms and another part served to collect the Collembola to be introduced within them as explained below. 2009), were made of 5 plastic tubes arranged in a row-like configuration (total length $25 \mathrm{~cm}$, diameter $5 \mathrm{~cm}$ ). Each plastic tube corresponds to a section (numbered 1 to 5) bound together with adhesive tape, and sealed at each end with a plastic cap to prevent escape of animals (Fig. 1). For all tests, the organic substrate filling the compartments 1 to 5 of the microcosms was first sterilized by autoclaving at $105^{\circ} \mathrm{C}$ with two successive cycles of $1 \mathrm{~h}$ separated by $24 \mathrm{~h}$, then was sieved at $5 \mathrm{~mm}$ and carefully mixed before filling the different 101 sections.

102 Only the last part of the microcosms (section 5) differentiated the treatments:

103 - In the "microflora bio-assay", abbreviated $M$ in the following text, the sterilised 104 organic substrate dedicated to section 5 was reinoculated with soil microflora. A suspension of soil microflora was obtained after shaking $500 \mathrm{~g}$ of fresh organic 
substrate with $2.5 \mathrm{~L}$ of distilled water during $1 \mathrm{~h}$. The suspension was then filtered in two successive steps: first at $250 \mu \mathrm{m}$ and then using filters for qualitative microbial analysis (DURIEUX $n^{\circ} 149$ ). Ten millilitres of this suspension were transferred into each section 5 . This was repeated three times waiting $12 \mathrm{~h}$ between each inoculate. The same amount of distilled water was added to the other sections.

- In the "microflora+plant bio-assay", abbreviated M+P in the following text, one week after reinoculation of microflora, a plant (Hyacinthoides non-scripta (L.) Chouard ex Rothm., 1944) was added to section 5. Plants of the same morphology, around $10 \mathrm{~cm}$ tall, were collected in the forest, their roots were washed with distilled water and slightly cut to homogenise their morphology.

- In the "control bio-assay", abbreviated C in the following text, no further treatment was applied to the substrate of the section 5 compared to compartments 1 to 4 . In

121 introduction of the microflora suspension and the plants. Whatever the treatments, the

122 section 5 was separated from section 4 with a fine-mesh $(20 \mu \mathrm{m})$ plastic gauze to minimize

123 or exclude propagation of soil biota (microflora and roots) to adjacent compartments. In

124 each microcosm one centimetre was left empty between the substrate and the top of the 125 tubes to allow movement of surface dwelling collembolans. Four replicate microcosms were 126 used per treatment. 
From the non-sterilised part of the organic substrate collected, Collembola were

130 extracted alive using the dry funnel method above trays filled with moist clay as collectors

131 and then were transferred using a pooter to sections 1 through a hole $(1.2 \mathrm{~cm}$ diameter $)$

132 pierced on top of the tubes. After springtails were introduced, the hole was closed with a

133 plastic plug caps. The amount of substrate used for extracting Collembola corresponded to

134 the amount of substrate used to fill in the sections 1 plus $50 \%$ to obviate for mortality during

135 the transfer into the microcosms. Because it is known that death odour is repellent for

136 Collembola (Nilsson and Bengtsson, 2004), a two-week period was left before introducing

137 them into the microcosms.

138 The microcosms were incubated at room temperature for 12 days. We selected this time

139 lapse because to the light of preliminary experiments 12-day was judged enough to allow

140 migration but not reproduction to occur. However, we cannot rule out that some deposition

141 and hatching of eggs deposited in the meantime by fertile females probably occurred,

142 thereby increasing the error but not the treatment effect. The sections were then carefully

143 separated and the collembolans were recovered from them by the dry-funnel method,

144 counted and determined at species level following several keys (Gisin, 1960; Hopkin, 2007).

145 The soil water content in the different microcosms was determined by drying $5 \mathrm{~g}$ of soil at

$146105{ }^{\circ} \mathrm{C}$ for $48 \mathrm{~h}$ (Alef and Nannipieri, 1995). Furthermore, at the end of the experiment, the

147 microbial $\mathrm{C}$ biomass ( $\mathrm{Cmic}$ ) of sections 5 was determined by means of the fumigation-

148 extraction method (Jenkinson and Powlson, 1976). Before and after fumigation, $20 \mathrm{~g}$ of fresh

149 soil was shaken for $1 \mathrm{~h}$ in a solution of $\mathrm{K} 2 \mathrm{SO} 4$ at $0.05 \mathrm{M}$ then filtered at $0.45 \mu \mathrm{m}$ and

150 analysed for dissolved organic C on a Shimadzu-TOC-L series.

\subsection{Data Analysis}


154 each life-form and finally of the whole assemblage, using the following calculation:

155 Exploratory behaviour $=(n 2+n 3+n 4) / N * 100$

156 Where $\mathrm{ni}=$ number of individuals recovered in section $\mathrm{i}$, and $\mathrm{N}=$ total number of individuals

157 within the microcosm.

158 In parallel we also evaluated the Collembola movement according to the following formula:

159 Mean covered distance $=p 1 * d 1+p 2 * d 2+p 3 * d 3+p 4 * d 4$

160 Where $\mathrm{pi}=$ proportion of individuals in section $\mathrm{i}$ from the total recovered in sections $1-4$, and

$161 \mathrm{di}=$ distance from the application point to the centre of section $\mathrm{i}$.

162 For each level of observation (assemblage, life-form and species of Collembola) the

163 impact of the factor "Treatment" upon the exploratory behaviour and the mean covered

164 distance was tested by means of General Linear Models (GLM). GLM with single categorical

165 predictor can be called a one-way Anova design. The same test was applied for the microbial

$166 \quad$ C biomass and the soil water content.

167 For each treatment, differences between the percentages of Collembola recovered within

168 each section were tested by GLM with Section as fixed factor. Prior to analyses, percentage

169 data were arcsin transformed. In all cases, significant differences between means were

170 tested at the $5 \%$ level using the Tukey HSD test. All statistical analyses were performed with

171 the STATISTICA ${ }^{\circledR}$ software package (version 7.0, Statsoft ${ }^{\circledR}$, Tulsa, OK).

172 


\section{RESULTS}

174 The microbial $C$ biomass differed between the treatments $(F=38.1, p<0.0001)$ with on

175 average almost 18 times more $\mathrm{Cmic}$ in the $\mathrm{M}+\mathrm{P}$ treatment than in the Control and twice

176 more than in the M treatment (Fig. 2). In opposite, no difference of soil water content could

177 be established between the treatments $(F=0.907, p=0.44)$ with an overall mean $( \pm$ SD) of

$17853.2( \pm 2.6) \%$ of dry weight.

179 There were no significant differences between the treatments regarding the total amount

180 of springtails recovered from the microcosms $(F=2.25, p=0.16)$ with an overall mean $( \pm S D)$

181 of $76.1( \pm 15.4)$ individuals per microcosm.

182

\subsection{Collembolan Assemblages}

The mean $( \pm S D)$ exploratory behaviour in the control bio-assay $(C)$ was of $15.3 \%( \pm 5.3)$ and increased to $62.0 \%( \pm 11.5)$ in the microflora treatment $(\mathrm{M})$ and to $78.7 \%( \pm 5.6)$ in the microflora+plant treatment $(M+P)$.

The mean covered distance of total collembolan differed between all the treatments $(F=$ $50.37, \mathrm{p}<0.001)$. It continuously increased from $0.9( \pm 0.3) \mathrm{cm}$ in $C$ through $4.7( \pm 1.0) \mathrm{cm}$ in $M$ to $7.4( \pm 1.2) \mathrm{cm}$ within $M+P$.

190 The amount of collembolan found in the different sections differed in the $\mathrm{C}$ and the $\mathrm{M}$

191 treatment $(F=302.6, p<0.001$ and $F=11.8, p<0.001$, respectively $)$. In $C$, only less than $3 \%$

192 of the springtails moved beyond the section 2 (Fig. 3A). When adding microflora in the fifth

193 separated section, a maximum of individuals was found in section 2 (about $40 \%$ of the total

194 amount). Still in $\mathrm{M}$, the percentage of collembolans recovered in sections 1 and 2 did not

195 differ but both were significantly higher than in sections 3 and 4 . A total of $25 \%$ of the 
collembolans were found in these two last sections (Fig. 3B). In $M+P$, a similar percentage of

197 individuals was recovered in all sections ( $F=3.1, p>0.05$; Fig. $3 C$ ).

198

\subsection{Life-forms}

The factor "life-form" had a significant effect on the exploratory behaviour ( $F=13.83 ; p<$ 0.001). Epedaphic collembolans had an overall exploratory behaviour of $76.2 \%$ significantly higher than both hemiedaphic and euedaphic, with similar values of $56.5 \%$ and $48.4 \%$, respectively.

The different life-forms showed a similar pattern of exploratory behaviour across the treatments. Each life-form had similar values in both $M$ and $M+P$, being twice higher for epedaphic and 5 to 6 times higher for hemiedaphic and euedaphic than in C (Table 1 ). Concomitantly, the mean covered distance was also influenced by the factor "life-form" ( $F=$ $22.2, p<0.001$ ) with on average $7.3 \mathrm{~cm}$ covered by the epedaphic which was $73.8 \%$ more than for hemiedaphic and $82.5 \%$ more than euedaphic. The mean distance covered by the epedaphic was almost twice higher in $\mathrm{M}$ and $\mathrm{M}+\mathrm{P}$ than in $\mathrm{C}$ (Fig. 4). The same pattern was

211 obtained for the euedaphic springtails with $7.1( \pm 0.8) \mathrm{cm}$ covered in M+P and only $0.6( \pm$ $0.2) \mathrm{cm}$ covered in C. Finally the distance covered by the hemiedaphic was different for each bio-assay ranging from $0.9( \pm 0.3) \mathrm{cm}$ in $\mathrm{C}$ to $7.6( \pm 1.7) \mathrm{cm}$ in $\mathrm{M}+\mathrm{P}$. While strong differences existed in the mean distance covered between the life-forms in the $C$ and $M$ treatments, these differences disappeared in M+P (Fig. 4).

\subsection{Species-level}

218 Four different groups of species could be distinguished according to their exploratory response to the treatments (Table 2). Group 1 was made of species showing a foraging 
pattern (mean covered distance) that did not differ between the treatments: Mesaphorura macrochaeta and Friesea truncata. On average $( \pm S D)$, species of this group covered a distance of $4.2( \pm 2.7) \mathrm{cm}$. Lepidocyrtus lanuginosus, Entomobrya multifasciata, Sminthurinus signatus, and Folsomia quadrioculata belong to a second group with a mean distance

224 covered significantly modified by the addition of food resources but without differences between $\mathrm{M}$ and $\mathrm{M}+\mathrm{P}$ treatments. In the control treatment, members of this group covered on average $( \pm S D)$ a distance of $2.3( \pm 1.0) \mathrm{cm}$, while in $\mathrm{M}$ and $\mathrm{M}+\mathrm{P}$ considered together they covered a mean $( \pm$ SD) distance of $7.8( \pm 1.1) \mathrm{cm}$. The group 3 was only made of Protaphorura armata which was only affected by the $\mathrm{M}+\mathrm{P}$ treatment. While in $\mathrm{C}$ and $\mathrm{M}$

229 considered together, $P$. armata covered a mean ( \pm SD) distance of $0.9( \pm 1.8) \mathrm{cm}$, the 230 addition of a plant $(M+P)$ increased its movement to reach an average $( \pm S D)$ distance of 7.9 $231( \pm 3.2) \mathrm{cm}$. Finally the fourth group was made of species showing significantly different mean 232 distances covered for each treatment: Isotomiella minor and Parisotoma notabilis.

\section{DISCUSSION}

Movements of animals can be considered over a wide range of spatial and temporal scales. In large-scale movements they migrate in response to a deteriorating habitat, 237 optimum breeding conditions or physiological signals, basically independent of resource 238 limitation. Passive dispersal has been also advocated to explain large-scale dispersal of 239 collembolans (Hawes, 2008). Small-scale movements, covering only a small part of a 240 population, are often due to local resource limitations (e.g. space or food) and may be 241 triggered by feeding activities or by intraspecific antagonisms (Bowler and Benton, 2005; 242 Bullock et al., 2002; Clobert et al., 2001). Our study clearly demonstrates the importance of 243 foraging behaviour, based on distant patch quality recognition, for the movement of 
244 collembolans. The absence of food at a distant point leads to almost no exploratory

245 behaviour of springtails. However, enriching the last part of our devices with a food item had

246 a significant effect on the distribution of Collembola. Collembolans are known to move

247 towards sources of $\mathrm{CO}_{2}$, which they locate in a similar way as plant parasitic nematodes find

$248 \mathrm{CO}_{2}$-emitting roots in soil (Klinger, 1965). This may explain the higher dispersal distance

249 covered by Collembola when a plant was introduced in the distant section. Furthermore, the

250 higher microbial $\mathrm{C}$ biomass in the $\mathrm{M}+\mathrm{P}$ treatment may also, through a higher amount of 251 volatile compounds, be responsible for the higher attraction of springtails. The highest mean 252 dispersal distance estimated in our study $(4.3 \mathrm{~cm} /$ week $)$ is in the range of values reported 253 previously in forest soil (Ojala and Huhta, 2001). This may indicate that our design did not 254 cause a strong bias in springtails behaviour, at least at the community level.

255 According to morphological traits of collembolan life-forms, a positive gradient of 256 efficient dispersal is often observed from euedaphic to epedaphic species (Ojala and Huhta, 257 2001). This is only partly supported by our data. Epedaphic species had the highest mean 258 dispersal distance whatever the treatment, but no difference was found between the mean 259 dispersal distance of euedaphic and hemiedaphic species in the different treatments. 260 Apparently, as stated by Sjögren (1997), jumping abilities of springtails species do not fully 261 correlate to their dispersal rates. Interestingly, however, the exploratory behaviour of 262 epedaphic species was weakly impacted by the different treatments while the addition of 263 different food resources strongly modified the patterns of both hemi- and euedaphic 264 species. Mechanisms responsible for migration of epedaphic species might differ from those 265 in play for the two other life-forms. Epedaphic species, living in a fluctuating environment in 266 opposite to hemi or euedaphic, are rather considered as $r$ species. Such strategists are often 267 good dispersers and pioneer species with therefore an exploratory behaviour not necessarily 
directed toward a more favourable habitat. However our design, specifically the humified

substrate used, offered rather unnatural conditions to epedaphic species compared to hemi

270 and euedaphic species. This may have affected their behaviour and consequently their

271 movement. It is thus difficult to conclude if we underestimated the distance they could

272 covered due to the disadvantage of the substrate or if we overestimated it because they

273 wanted to get away from this unnatural condition. Our results regarding this life-form might

274 thus be interpreted with caution.

275 Even if differences between life-forms were detected, our results also revealed

276 differences of exploratory pattern between species classified into the same life-form. For

277 example, half of the euedaphic species had a similar average distance of dispersal between

278 the three treatments while the other half showed strong differences of distance covered

279 between the treatments. This supports the view of several authors (Hågvar, 1983; Sjögren,

280 1997) concluding that morphologically equal species can show very different dispersal rates.

281 Feeding behaviour may be an important point in this respect. Through a stable isotope

282 approach, three feeding guilds in springtails were distinguished not correlated to life-forms

283 (Chahartaghi et al., 2005): phycophages/herbivores, primary decomposers and secondary

284 decomposers. According to data given by these authors, our four groups do not correspond

285 to the food habits revealed by $\delta 15 \mathrm{~N}$ signatures, because our group 2 (migration affected by

286 food resources) was made of both primary and secondary decomposers. This can be

287 explained by the fact that in our experiment species with longer legs and furcula moved over

288 longer distances, which was also shared by species strongly attracted to microbes and/or

289 roots. Although our design was not purposed to demonstrate it, our results point to a

290 behavioural trade-off between dispersal rate and attraction to food resources. 
The distance covered by Protaphorura armata, one of the few euedaphic species to be

292 phytophagous (Hopkin, 1997), was highest when a plant was introduced in a distant patch.

293 Bengtsson et al. 1994a also found $P$. armata to be attracted by mycorrhizal fungi. By 294 contrast, Friesea truncata a predatory euedaphic species, covered the same distance 295 whatever the treatment. Although not significant, F. truncata showed a slight tendency to cover a higher distance in the microflora and plant treatment. It is probable that this species

297 feeding on eggs of collembolan (Hopkin 1997) started to respond to the overall collembolan 298 movement and that extending the experiment would have reinforced this process. 299 Nevertheless besides feeding behaviour, size should also be considered. For example, 300 Mesaphorura macrochaeta, though known as fungivorous only showed a tendency to 301 migrate more when a food source was tied at a distant patch. The very small size of $M$. 302 macrochaeta (the smallest species of our experiment) and thus its low active mobility might 303 explain this pattern. Finally, differences of pattern between quite similar species in terms of 304 ecology, for example Parisotoma notabilis and Folsomia quadrioculata, are interesting to 305 notice, because rather unexpected. However, Ojala et al. 2001 also found that $F$. 306 quadrioculata covers lower distance, by $34 \%$, than $P$. notabilis in field conditions. Biotic 307 interactions (intra or interspecific) may also surely play a role. Bengtsson et al. 2002 308 documented a positive relationship between conspecific density and migration pattern of a 309 soil collembolan. Our study was not design to test for this specific factor, but it may have 310 played a role on the observed pattern. Furthermore we cannot exclude the fact that our 311 design favoured or in contrary disadvantaged the movement of several species. For example, 312 it is known that juveniles and adults may have very different behaviour and dispersal 313 patterns (Ronce, 2007). 

reproduce the real environment of soil animal communities, our study revealed that the

316 presence of food (roots and/or microflora) influenced the migration of collembolan species

317 which differ according to the four criteria: morphology, life-form, feeding guild and dispersal

318 rate. We showed that none of them fully explained the active foraging of species placed at 319 distance from a food source, pointing to species-specific response patterns that can only be 320 explained by a combination of several criteria. Awaiting more complete screening, Table 2, 321 although based on a little number of species, can be suggested as a guide for field functional 322 ecologists.

Acknowledgements

326 The study was carried out within the context of the TRACES project funded by the French 327 Ministry of Ecology, Energy and Sustainable Development (MEEDDM) through the GESSOL 3 3282009 call for projects. We thank all project partners, as well as the members of the Ecodiv 329 lab (Normandie Univ, Rouen) for invaluable technical assistance and stimulating discussions. 
332 Alef, K., Nannipieri, P., 1995. Methods in applied soil microbilogy and biochemistry. 333 Academic Press, London.

334 Auclerc, A., Libourel, P.A., Salmon, S., Bels, V., Ponge, J.F., 2010. Assessment of movement 335 patterns in Folsomia candida (Hexapoda: Collembola) in the presence of food. Soil Biol. $336 \quad$ Biochem. 42, 657-659.

337 Auclerc, A., Ponge, J.F., Barot, S., Dubs, F., 2009. Experimental assessment of habitat 338 preference and dispersal ability of soil springtails. Soil Biology and Biochemistry 41, 15963391604.

340 Bengtsson, G., Hedlund, K., Rundgren, S., 1994a. Food- and density-dependent dispersal: 341 Evidence from a soil collembolan. J. Animal Ecol. 63, 513-520.

342 Bengtsson, G., Rundgren, S., 1988. the Gusum case: a brass mill and the distribution of soil 343 Collembola. Can. J. Zool. 66, 1518-1526.

344 Bengtsson, G., Rundgren, S., Sjögren, M., 1994b. Modelling dispersal distances in a soil 345 gradient: the influence of metal resistance, competition, and experience. Oikos 71, 13-23. 346 Bengtsson, G., Rydén, T., Öhrn, M.S., Wiktorsson, M., 2002a. Statistical analysis of the 347 influence of conspecifics on the dispersal of a soil collembola. Theoretical Population $348 \quad$ Biology 61, 97-113.

349 Bengtsson, G., Rydén, T., Öhrn, M.S., Wiktorsson, M., 2002b. Statistical Analysis of the 350 Infulence of Conspecifics on the Dispersal of a Soil Collembola. Theoretical Population 351 Biology 61, 97-113.

352 Bowler, D.E., Benton, T.G., 2005. Causes and consequences of animal dispersal strategies: 353 relating individual behaviour to spatial dynamics. Biol. Rev. 80, 205-225. 
354 Bullock, J.M., Kenward, R.E., Hails, R.S., 2002. Dispersal Ecology. Blackwell Science Ltd, 355 Oxford, UK.

356 Chahartaghi, M., Langel, R., Scheu, S., Ruess, L., 2005. Feeding guilds in Collembola based on 357 nitrogen stable isotope ratios. Soil Biol. Biochem 37, 1718-1725.

358 Clobert, J., Danchin, E., Dohndt, A.A., Nichols, J.D., 2001. Dispersal. Oxford University Press, 359 Oxford, UK.

360 Dieckmann, U., O’Hara, B., Weisser, W., 1999. The evolutionary ecology of dispersal. Trends 361 in Ecology and Evolution 14, 88-90.

362 Filser, J., 2002. The role of Collembola in carbon and nitrogen cycling in soil. Pedobiologia 46, 234-245.

364 Gisin, H., 1960. Collembolenfauna Europas. Museum d'histoire Naturelle, Genf.

365 Hagvar, S., 2000. Navigation and behaviour of four Collembola species migrating on the snow surface. Pedobiologia 44, 221-233.

Hågvar, S., 1983. Collembola in Norwegian coniferous forest soils - II. Vertical distribution. Pedobiologia 25, 383-401.

Hassall, M., Adl, S., Berg, M., Griffiths, B., Scheu, S., 2006. Soil fauna-microbe interactions: towards a conceptual framework for research. European Journal of Soil Biology 42, Supplement 1, S54-S60.

Hawes, T.C., 2008. Aeolian fallout on recently deglaciated terrain in the high Arctic. Polar Biol 31, 295-301.

Hopkin, S., 1997. Biology of the springtails - Insecta: Collembola. Oxford University Press, New York.

Hopkin, S.P., 2007. A key to the Collembola (springtails) of Britain and Ireland. Field Studies Council. 
Jenkinson, D.S., Powlson, D.S., 1976. The effect of biocidal treatments on metabolism in soil I. Fumigation with chloroform. Soil Biol. Biochem. 8, 167-177.

Klinger, J., 1965. On the orientation of plant Nematodes and of some other soil animals Nematologica 11, 4-18.

Lenoir, L., 2003. Response of the foraging behaviour of red wood ants (Formica rufa group) to exclusion from trees. Agricultural and Forest Entomology 5, 183-189.

Levin, S.A., Muller-Landau, H.C., Nathan, R., Chave, J., 2003. The ecology and evolution of seed dispersal: A theoretical perspective. Annual Review of Ecology Evolution and Systematics $34,575-604$.

MacMillan, K., Haukeland, S., Rae, R., Young, I., Crawford, J., Hapca, S., Wilson, M., 2009. Dispersal patterns and behaviour of the nematode Phasmarhabditis hermaphrodita in mineral soils and organic media. Soil Biol. Biochem. 41, 1483-1490.

Mathieu, J., Barot, S., Blouin, M., Caro, G., Decaens, T., Dubs, F., Dupont, L., Jouquet, P., Nai, P., 2010. Habitat quality, conspecific density, and habitat pre-use affect the dispersal behaviour of two earthworm species, Aporrectodea icterica and Dendrobaena veneta, in a mesocosm experiment. Soil Biol. Biochem. 42, 203-209.

Mitchell, R., 1970. An analysis of dispersal in mites. The American Naturalist 104, 425-431.

Nathan, R., 2001. The challenges of studying dispersal. Trends in Ecology \& Evolution 16, 491-493.

Nilsson, E., Bengtsson, G., 2004. Death odour changes movement pattern of a Collembola. Oikos 104, 509-517.

Ojala, R., Huhta, V., 2001. Dispersal of microarthropods in forest soil. Pedobiologia 45, 443450. 
401 Petersen, H., 2002. General aspects of collembolan ecology at the turn of the millennium.

402 Pedobiologia 46, 246-260.

403 Ronce, O., 2007. How Does It Feel to Be Like a Rolling Stone? Ten Questions About Dispersal 404 Evolution. Ann. Rev. Ecol. Syst. 38, 231-253.

405 Rusek, J., 1989. Ecology of Collembola, in: Dallai, R. (Ed.), 3rd International Seminar on 406 Apterygota. Univ. Siena Press, Siena, pp. 271-281.

407 Salmon, S., Ponge, J.F., 2001. Earthworm excreta attract soil springtails: laboratory 408 experiments on Heteromurus nitidus (Collembola: Entomobryidae). Soil Biol. Biochem 33, $409 \quad 1959-1969$.

410 Schallhart, N., Tusch, M.J., Staudacher, K., Wallinger, C., Traugott, M., 2011. Stable isotope 411 analysis reveals whether soil-living elaterid larvae move between agricultural crops. Soil 412 Biology and Biochemistry 43, 1612-1614.

413 Sjögren, M., 1997. Dispersal rates of Collembola in metal polluted soil. Pedobiologia 41, 506$414 \quad 513$.

415 Winker, K., 2000. Evolution: Migration and speciation. Nature 404, 36-36.

416 
418 Table 1: Mean exploratory behaviour (in percentage) with standard deviations of 419 collembolan life-forms within three treatments corresponding to different food sources tied 420 to a distant patch. Means of the same life-form sharing identical letters are not significantly 421 different (Tukey HSD test). C: control; M: microflora treatment; $M+P$ : microflora and plant 422 treatment. Ep: Epedaphic, He: Hemiedaphic, Eu: Euedaphic.

\section{Treatments}

\begin{tabular}{lccc} 
& $\mathrm{C}$ & $\mathrm{M}$ & $\mathrm{M}+\mathrm{P}$ \\
\hline Epedaphic & $45.6^{\mathrm{B}}(26.5)$ & $91.1^{\mathrm{A}}(6.0)$ & $91.2^{\mathrm{A}}(6.8)$ \\
Hemiedaphic & $17.2^{\mathrm{B}}(5.8)$ & $66.4^{\mathrm{A}}(21.2)$ & $86.0^{\mathrm{A}}(7.9)$ \\
Euedaphic & $11.3^{\mathrm{B}}(4.4)$ & $58.9^{\mathrm{A}}(6.9)$ & $74.9^{\mathrm{A}}(5.0)$
\end{tabular}


Table 2: Mean covered distance (in $\mathrm{cm}$ ) with standard deviations of different collembolan species covered after 12 days within three treatments corresponding to different food

426 sources tied to a distant patch. Species are grouped according to their response pattern.

427 Means of the same species sharing identical letters are not significantly different (Tukey HSD

428 test; P level of significance: n.s. $=$ not significant; $\left.{ }^{* *}=<0.01 ; * *=<0.001\right)$. C: control; M:

429 microflora treatment; M+P: microflora and plant treatment. Ep: Epedaphic, He:

430 Hemiedaphic, Eu: Euedaphic.

\begin{tabular}{|c|c|c|c|c|c|c|c|}
\hline Group & Species & $\begin{array}{l}\text { Life- } \\
\text { form }\end{array}$ & $\mathrm{F}$ & $P$ & C & M & $M+P$ \\
\hline \multirow[t]{2}{*}{1} & Mesaphorura macrochaeta & $\mathrm{Eu}$ & 3.2 & n.s. & $\begin{array}{l}2.0^{A} \\
(1.0)\end{array}$ & $\begin{array}{l}5.4^{\mathrm{A}} \\
(3.4)\end{array}$ & $\begin{array}{l}6.0^{A} \\
(2.2)\end{array}$ \\
\hline & Friesea truncata & $\mathrm{Eu}$ & 4.2 & n.s. & $\begin{array}{l}1.1^{\mathrm{A}} \\
(1.3)\end{array}$ & $\begin{array}{l}5.2^{A^{A}} \\
(2.7)\end{array}$ & $\begin{array}{l}4.2^{A^{\prime}} \\
(2.0)\end{array}$ \\
\hline \multirow[t]{4}{*}{2} & Lepidocyrtus Lanuginosus & Ep & 8.9 & $* *$ & $\begin{array}{l}5.7^{B} \\
(2.3)\end{array}$ & $\begin{array}{l}11.2^{\mathrm{A}} \\
(1.0)\end{array}$ & $\begin{array}{l}10.6^{A} \\
(2.5)\end{array}$ \\
\hline & Entomobrya multifasciata & Ep & 8.3 & $* *$ & $\begin{array}{l}1.9^{B} \\
(2.2)\end{array}$ & $\begin{array}{l}7.2^{A} \\
(1.6)\end{array}$ & $\begin{array}{l}6.9^{A} \\
(2.4)\end{array}$ \\
\hline & Folsomia quadrioculata & $\mathrm{He}$ & 66.0 & $* * *$ & $\begin{array}{l}0.6^{B} \\
(0.3)\end{array}$ & $\begin{array}{l}4.3^{A} \\
(0.8)\end{array}$ & $\begin{array}{l}4.8^{\mathrm{A}} \\
(0.6)\end{array}$ \\
\hline & Sminthurinus signatus & $\mathrm{He}$ & 22.6 & $* * *$ & $\begin{array}{l}0.9^{B} \\
(1.2)\end{array}$ & $\begin{array}{l}7.8^{A} \\
(2.5)\end{array}$ & $\begin{array}{l}9.9^{A^{A}} \\
(1.9)\end{array}$ \\
\hline 3 & Protaphorura armata gr. & $\mathrm{Eu}$ & 12.9 & $* *$ & $\begin{array}{l}0.0^{\mathrm{B}} \\
(0.0)\end{array}$ & $\begin{array}{l}1.7^{\mathrm{B}} \\
(2.4)\end{array}$ & $\begin{array}{l}7.9^{A} \\
(3.2)\end{array}$ \\
\hline \multirow[t]{2}{*}{4} & Isotomiella minor & $\mathrm{Eu}$ & 70.1 & $* * *$ & $\begin{array}{l}0.8^{\mathrm{C}} \\
(0.6)\end{array}$ & $\begin{array}{l}4.4^{B} \\
(0.9)\end{array}$ & $\begin{array}{l}9.3^{\mathrm{A}} \\
(1.5)\end{array}$ \\
\hline & Parisotoma notabilis & $\mathrm{He}$ & 92.7 & $* * *$ & $\begin{array}{l}0.2^{\mathrm{C}} \\
(0.3)\end{array}$ & $\begin{array}{l}3.8^{\mathrm{B}} \\
(0.8)\end{array}$ & $\begin{array}{l}10.9^{A} \\
(1.7) \\
\end{array}$ \\
\hline
\end{tabular}


Figure 2
Click here to download Figure: Fig 2 as is.xIsx

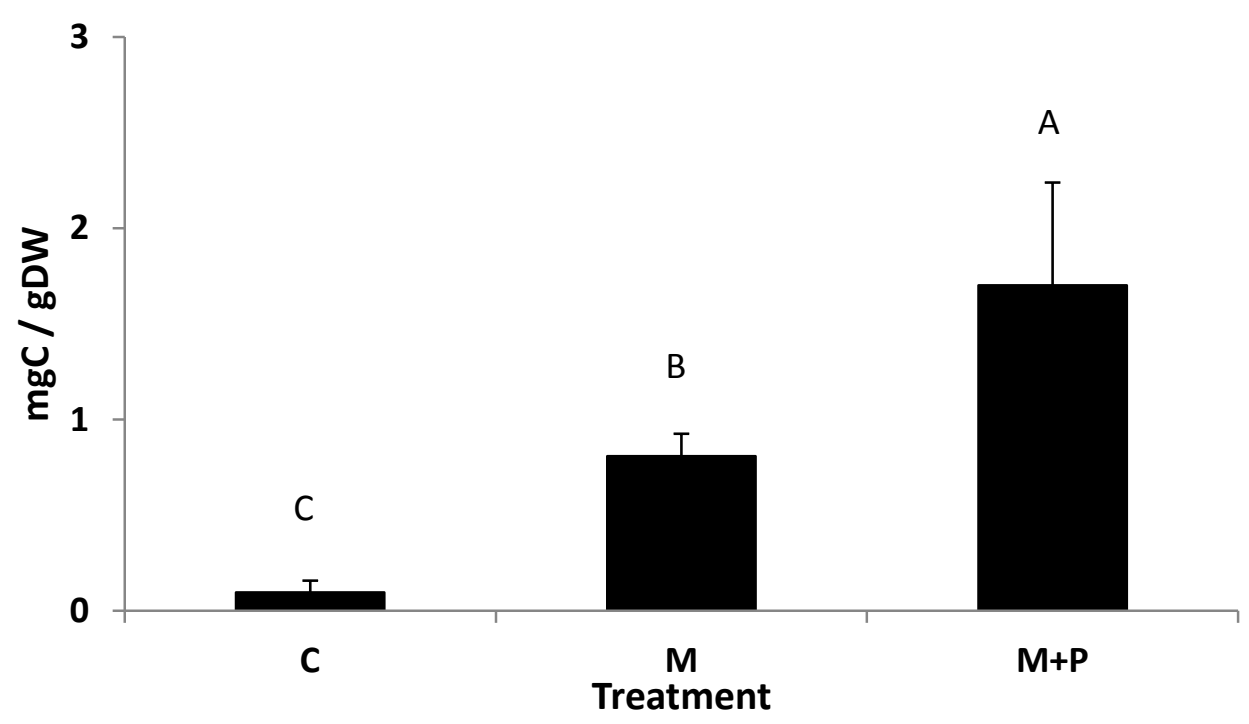


Click here to download Figure: Fig 3 as is.xlsx
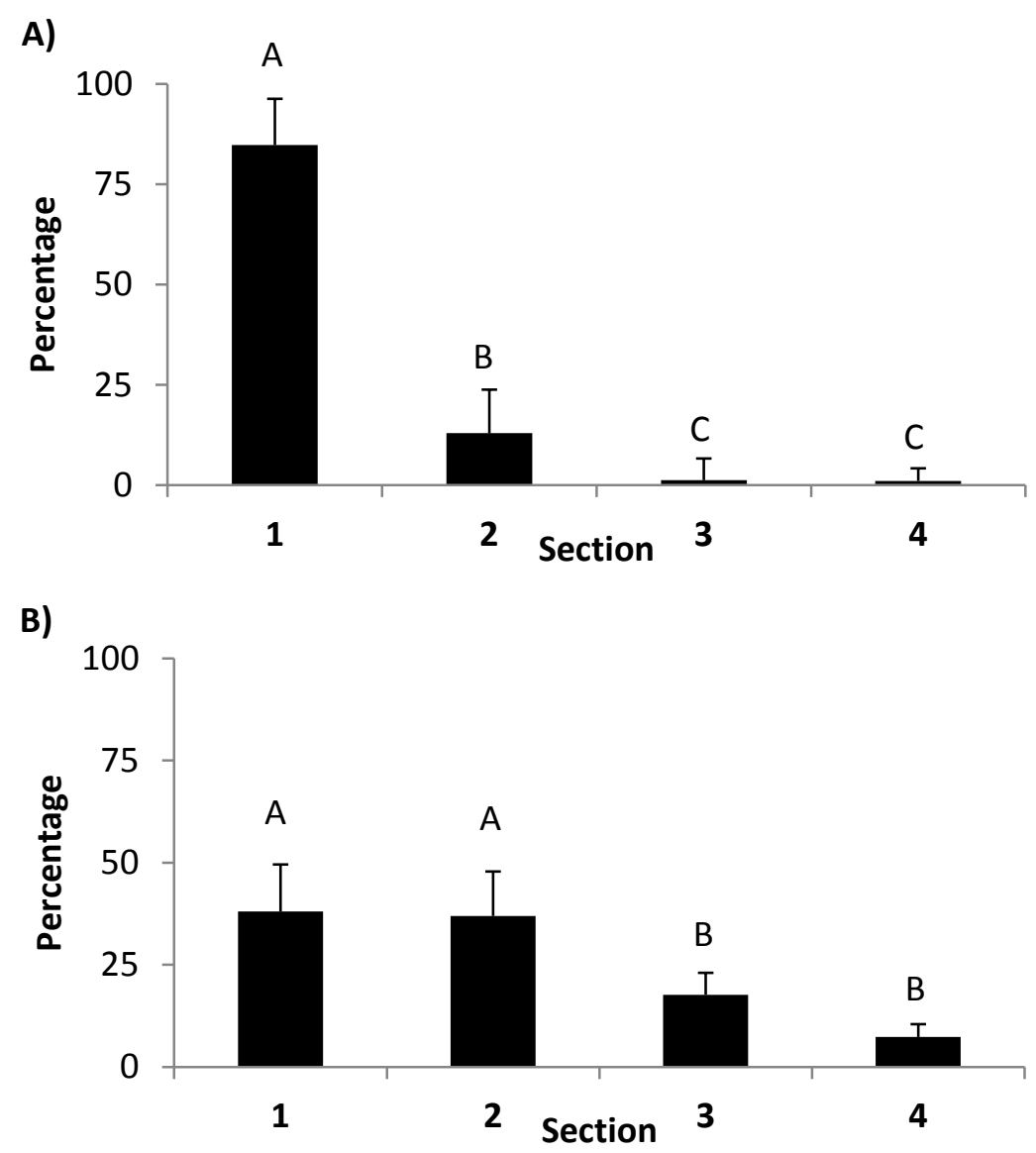

c)

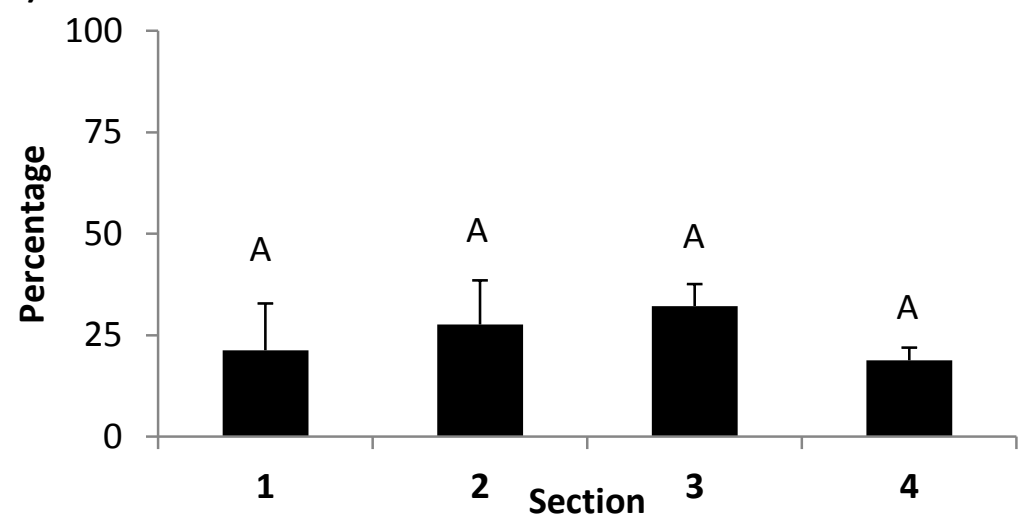


Figure 4
Click here to download Figure: Fig 4 as is.xIsx
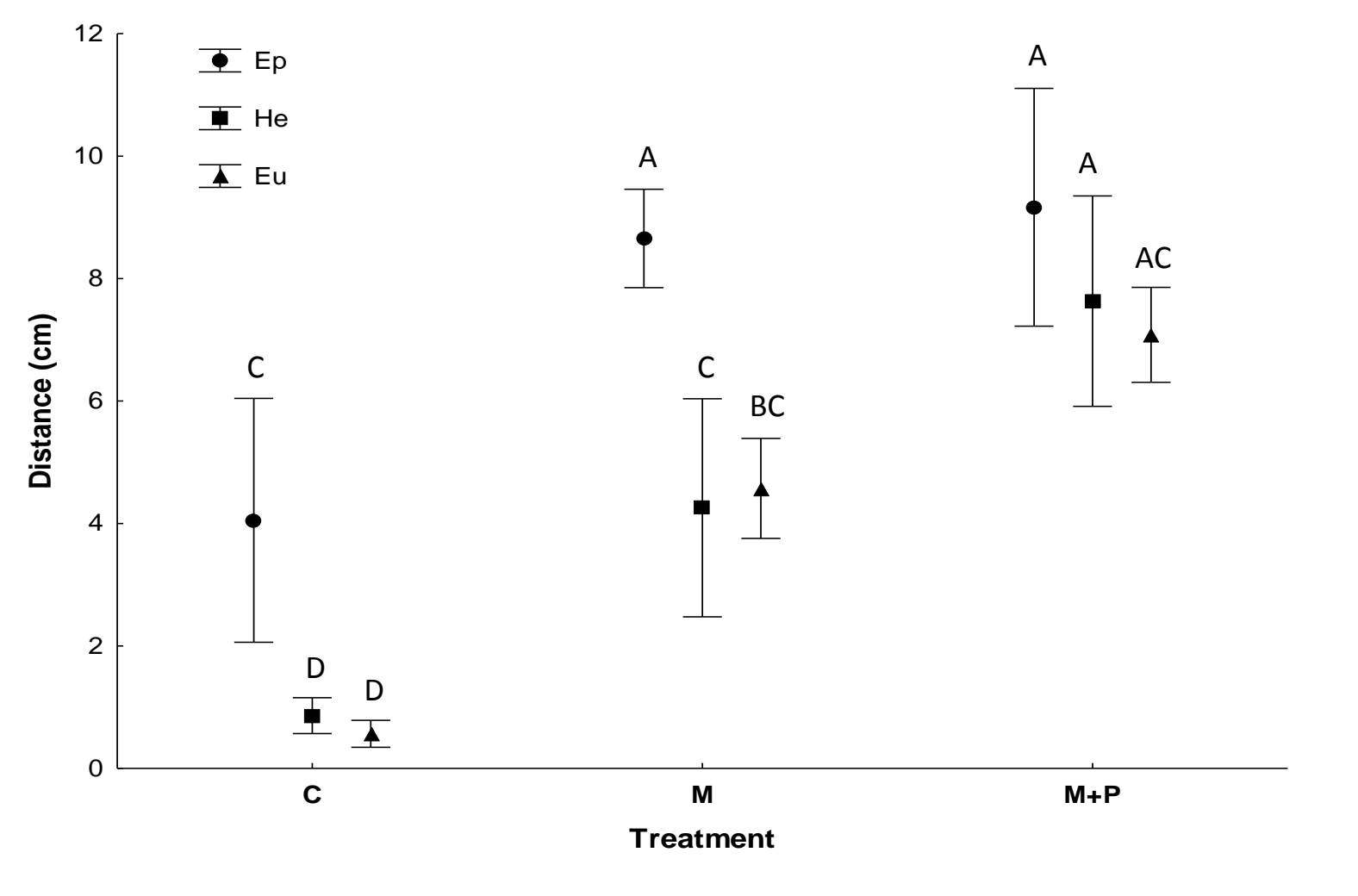


\section{APPENDIX 1}

Mean (and SD) number of Collembola found in each section (1 to 4) of the microcosms according to the different food sources placed at a distant point (section 5). C : control bioassays ; $M$ : microflora bio-assays ; $M+P$ : microflora and plant bio-assays

\begin{tabular}{cccc}
\hline Section & $\mathrm{C}$ & $\mathrm{M}$ & $\mathrm{M}+\mathrm{P}$ \\
\hline 1 & $72(22.2)$ & $26.8(6.0)$ & $17.8(3.4)$ \\
2 & $10.3(2.2)$ & $26.8(8.7)$ & $23.5(7.4)$ \\
3 & $1(0.8)$ & $13(5.4)$ & $27.3(5.2)$ \\
4 & $1(0.8)$ & $5.5(3.1)$ & $16.3(8.6)$ \\
Total & $84.3(21.7)$ & $72(9.5)$ & $84.9(13.2)$ \\
\hline
\end{tabular}

